\title{
EVALUATION OF TWO ALFALFA LANDRACES FOR SALT TOLERANCE VIA SOME MORPHOLOGICAL AND BIOCHEMICAL TRAITS
}

(Received: 31.12 .2020)

\author{
By \\ Nahid A. A. Morsi, Mervat R. I. Sayed* and Fadia M. Sultan* \\ Cell Research Department, Field Crops Research Institute, and * Forage Crops Research \\ Department, Field Crops Research Institute, Agricultural Research Center, Giza, Egypt
}

\begin{abstract}
Alfalfa (Medicago sativa L.) is the most commonly grown forage crop worldwide. Salinity stress is an abiotic stress, which has harmful effects on germination, growth and yield of alfalfa. Seventeen alfalfa landraces were assessed for salt tolerance with seven salt levels 0,5 and $10 \mathrm{dSm}^{-1}$ of $\mathrm{NaCl}, 5$ and $10 \mathrm{dSm}^{-1}$ of $\mathrm{CaCl}_{2}$ and 5 and $10 \mathrm{dSm}^{-1}$ mixture of $\mathrm{NaCl}+\mathrm{CaCl}_{2}$, in a laboratory experiment to select the most salt tolerant alfalfa landrace and the most sensitive one, which were evaluated under greenhouse conditions. Regarding laboratory experiment, two alfalfa landraces, namely $\mathrm{L}_{12}$ and $\mathrm{L}_{3}$, were selected as the most salt tolerant and sensitive landraces, respectively. A significant decrease was observed in all traits with increasing salt levels. The results showed that 5 $\mathrm{dSm}^{-1} \mathrm{CaCl}_{2}$ levels had the least effect on all traits, than $\mathrm{NaCl}$ followed by their mixture concentrations of $\mathrm{NaCl}+\mathrm{CaCl}_{2}$. The most tolerant and the most sensitive alfalfa landraces were assessed by peroxidase (POX), polyphenyl oxidase (PPO) and alcohol dehydrogenase (ADH) systems under different salt concentrations. The POX, PPO and ADH isozyme activities showed up to 10,11 and 10 distinct polymorphic bands, respectively. Some new bands were appeared and/or disappeared under different salt types and concentrations for the most salt tolerant and/or the most sensitive alfalfa landraces. The activity of isozymes (band intensity) increased under all salinity treatments compared with the control. The increase of band intensity and appearance or disappearance of new bands may be an indication of an increase in isozymes activities under salinity conditions.
\end{abstract}

Key words: Alfalfa, Salinity, Isozyme activities, Landraces

\section{INTRODUCTION}

Soil salinization affects more than 800 million hectares of irrigated land and is a significant factor limiting agricultural productivity worldwide (Roy et al., 2014). Breeding salt tolerant crop varieties is therefore critical for the usage of these saline areas. Even though various traits had an association with salinity tolerance in crops, including ion exclusion, osmotic tolerance and tissue tolerance (Deinlein et al., 2014) a more comprehensive understanding of how plants respond to high salinity is still needed to facilitate the breeding of salt-tolerant crops.

In some crop species, the presence of salt in soil solution affects plants by reducing their ability to uptake water, resulting in slower growth as well as the toxic effects of salt ions accumulating inside the plant. These phases may occur simultaneously (Munns et al., 2006).

There are different types of salts in the soil and irrigation water that depress crops production, but $\mathrm{NaCl}$ is the most important because of its intricate damage on the plants and complex relationships with other ions in soil and plant (Ashraf, 2004). The effects of salinity can hamper plant germination; reduce plant growth and establishment, which can result in reducing yields or a complete loss of crop (Golbashy et al., 2010).

Alfalfa (Medicago sativa L.) is the most commonly grown forage worldwide, because of its lower production costs, high quality (digestibility and protein content) and seasonal distribution through the year (El-Sharkawy et al., 2017). Global alfalfa production is estimated around 454 million tons per year. Alfalfa is considered moderately tolerant to salt and can withstand an equivalent of $200 \mathrm{mM}$ sodium chloride. However, research has shown that a $7 \%$ decrease in alfalfa yields can be expected with each $1 \mathrm{dSm}^{-1}$ increase in saturation extract 
salinity (Emam et al., 2009).

There are high morphological variations existing between alfalfa cultivars. Such morphological variations noted in center of diversity among the germplasms led to the selection of the most salt tolerant cultivars (Soltani et al., 2012). Salinity research on alfalfa focused primarily on germination in the presence of $\mathrm{NaCl}$ (Carlson et al., 1983; Allen et al., 1986 and Dobrenz et al., 1989). Several reports indicated that alfalfa has the genetic potential for improving salt tolerance, and plant breeding may be the solution for increasing yield under saline conditions (Noble et al., 1984).

The behavior of morpho-physiological traits of alfalfa under salinity was studied by El-Sherif (2003) who found that the investigated genotypes differed significantly in most of the studied traits such as number of surviving plants, plant height, number of branches, leaf chlorophyll content, relative water content, dry and fresh yield.

Electrophoretic analysis of variant isozymes can provide a precise tool to characterize plant species and cultivars under salinity stress. Isozymes are mostly co-dominant with a simple Mendelian inheritance in most loci and it can be resolved for most plant species regardless of habitat, size or longevity (Mahgoub et al., 2016). Electrophoretic analysis of isozymes as genetic markers is quite useful in studies of developmental and taxonomic relationships. Electrophoretic techniques for isozyme polymorphisms were used as identification and quantification methods, which provide correlation between the altered expression of specific genes and changes in the environment. These changes in the expression of genes would be involved in adaptation and could be used as molecular markers for salt stress tolerance. The use of molecular markers, isozymes in particular, in basic genetic studies and breeding is widely generalized in many crop, weed and wild plant species, where their advantages and limitations have been extensively discussed(Yusefi et al.,2017).

The main purpose of this study: evaluation of seventeen alfalfa (Medicago sativa L.) landraces for their responses to different salinity concentrations by measuring the various parameters via laboratory experiment, selection of the most tolerant landrace and the most sensitive one and evaluate them under greenhouse experiment and molecularly tested them.

\section{MATERIALS AND METHODS}

This experiment was conducted during 20182019 at the laboratories of Cell Research Department and the greenhouse of Forage Crops Research Department, Field Crops Research Institute (FCRI), Agriculture Research Center (ARC), Giza, Egypt to evaluate and screen seventeen alfalfa landraces for salt tolerance with different salt concentrations of $\mathrm{NaCl}$ and $\mathrm{CaCl}_{2}$ separately or in mixtures under laboratory and greenhouse conditions.

\subsection{Plant material}

The investigated seventeen alfalfa (Medicago sativa L.) landraces were kindly obtained from Forage Crops Research Department, FCRI, $\mathrm{ARC}$, and their sources and origins are presented in Table (1).

\subsection{Laboratory experiment}

For laboratory germination, seeds of seventeen landraces of alfalfa were sterilized in

Table (1): Source and origin of the seventeen Egyptian alfalfa landraces.

\begin{tabular}{|c|c|c|c|c|c|}
\hline Landrace No. & Source & origin & Landrace No. & Source & origin \\
\hline 1 & Siwa Oasis & Siwa & 10 & New valley & Paris \\
\hline 2 & Siwa Oasis & Siwa & 11 & New valley & Paris \\
\hline 3 & Siwa Oasis & Siwa & 12 & New valley & Paris \\
\hline 4 & New valley & Mout & 13 & New valley & El Kasr \\
\hline 5 & New valley & Mout & 14 & New valley & El Kasr \\
\hline 6 & New valley & Mout & 15 & New valley & Balat \\
\hline 7 & New valley & Elmadasha & 16 & New valley & Balat \\
\hline 8 & New valley & Elmadasha & 17 & New valley & Balat \\
\hline 9 & New valley & Elmadasha & & & \\
\hline
\end{tabular}


sodium hypochlorite $(1 \%)$ then washed four times by distilled water. Twenty five seeds of each alfalfa landrace were germinated in $15 \mathrm{~cm}$ Petri plates on sterilized Whatman filter paper under six different salt concentrations, in addition to tap water as control, 5 and $10 \mathrm{dsm}^{-1}$ of sodium chloride $(\mathrm{NaCl}), 5$ and $10 \mathrm{dsm}^{-1}$ of calcium chloride $\left(\mathrm{CaCl}_{2}\right)$ and 5 and $10 \mathrm{dsm}^{-1}$ of mixture of $\mathrm{NaCl}$ and $\mathrm{CaCl}_{2}$ (1:2). Each plate, containing $5 \mathrm{ml}$ of salt solution, was sealed with parrafilm and incubated in a growth chamber at $25^{\circ} \mathrm{C}$. The experiment was replicated three times in a randomized complete block design. Germination percentage was estimated for 7days old seedlings, where the number of emerged seeds were counted and compared to number of seeds originally planted in each plate of the three replicates. Normal seedlings obtained from the standard germination test were used for seedling evaluation according to the rules of the International Seed Testing Association (ISTA, 1985). Seeds were considered germinated when the emergent radical reached $2 \mathrm{~mm}$. Germination percentage, plumule and radical lengths were measured.

\subsection{Greenhouse experiment}

A pot experiment was conducted in the greenhouse of Forage Crops Research Department, ARC, Giza, Egypt, in 2018 and 2019. From the laboratory experiment, the most salt tolerant landrace $\left(\mathrm{L}_{12}\right)$ and the most sensitive one $\left(L_{3}\right)$ were selected for evaluation under the different salt treatments, using three replicates in a split plot design. Forty two pots $(50 \mathrm{~cm})$, each pot containing $5 \mathrm{~kg}$ mixture of virgin sandy loam (soil was sieved to pass $2 \mathrm{~mm}$ screen and washed with tap water), and lined with plastic bags to prevent leaching. Forty seeds of each alfalfa landrace were sown in each pot. The soil used in the greenhouse experiment was analyzed physically and chemically (Table 2 ).

After 10 days, the plants were thinned by hand picking and leaving 30 plants in each pot. The potting soil was supplemented with the recommended dose of superphosphate fertilizer, $15.5 \% \quad \mathrm{P}_{2} \mathrm{O}_{2} \quad(150 \quad \mathrm{~kg} / \mathrm{fed})$ and potassium sulphate, $48 \% \mathrm{~K}_{2} \mathrm{O}(120 \mathrm{~kg} / \mathrm{fed})$. Ammonium sulphate $(21.7 \% \mathrm{~N})$ was added at a rate of 20 $\mathrm{kg} / \mathrm{fed}$. A total of three salt doses of the described concentrations were applied every

Table (2): Physical and chemical analysis of the used soil in a greenhouse experiment.

\begin{tabular}{|l|c|}
\hline Particle size distribution\% & \\
Coarsa sand \% & 49.80 \\
Fine sand \% & 40.80 \\
Silt \% & 2.60 \\
Clay \% & 6.80 \\
Texture & Sandy loam \\
\hline Chemical character & 7.40 \\
\hline Soil reaction pH $(1: 2.5)$ & 0.121 \\
Electric conductivity $\left(\mathrm{dsm}^{-1}\right)$ & 0.025 \\
Organic matter $(\%)$ & 0.57 \\
Calcium carbonate $(\%)$ & \\
\hline Availablemacronutrients $\left(\mathbf{m g k g}^{-1}\right)$ & 1.13 \\
\hline $\mathrm{N}(\%)$ & 3.94 \\
$\mathrm{P}$ & 175 \\
$\mathrm{~K}$ & \\
\hline $\mathrm{Soluble} \mathrm{Cations} \mathrm{\%}^{+1}$ & \\
$\mathrm{Ca}^{+2}$ & 1.96 \\
$\mathrm{Mg}^{+2}$ & 0.65 \\
$\mathrm{Na}^{+}$ & 1.16 \\
$\mathrm{Soluble} \mathrm{Anion} \mathrm{\%}^{\mathrm{HCo}_{3}}$ & \\
$\mathrm{Co}_{3}$ & \\
$\mathrm{Cl}^{-}$ & 1.45 \\
$\mathrm{So}_{4}$ & 0.01 \\
\hline
\end{tabular}


seven days. The first salt stress was applied at the two-leaf stage. The first cut was taken after 45 days from sowing, and the other three cuts were taken consequently every 35 days later. Four cuts only were obtained from these experiments, because the lethal effect of high mixture of salt $\mathrm{NaCl}+\mathrm{CaCl}_{2}$ concentration lead to death of plants. For each sample (4 cuts) means of five plants were gently uprooted to dry and weigh the roots. Plant height, leaf/stem ratio and dry matter yield (means of 5 plants) were estimated.

\subsection{Statistical analysis}

The data were statistically analyzed to compare the means through L.S.D. test at probability level of 0.05 as described by Gomez and Gomez (1984). Bartlett's test was conducted to test the homogeneity of errors variances. The test was not significant for all assessed traits, so the two season's data were combined.

\subsection{Biochemical analyses}

\subsubsection{Isozyme molecular studies}

Isozyme extraction from the most tolerant and the most sensitive alfalfa landraces was conducted under different salt concentrations using peroxidase (POX), poly phenyl oxidase
(PPO) and alcohol dehydrogenase (ADH) systems. Isozyme fractions were performed according to Stegmann et al. (1985). The gels were stained after electrophoresis according to enzyme system and incubated at $37^{\circ} \mathrm{C}$ in the dark for complete staining after adding the appropriate substrate and staining solution according to Jonathan and Wendel (1990). For statistical analysis, the polymorphic bands were scored as present (+) or absent (-).

\section{RESULTS AND DISCUSSION}

\subsection{Lab experiments}

\subsubsection{Germination percentage}

Combined over two seasons means of germination percentage of seventeen alfalfa landraces as affected by different salt concentrations are presented in Table (3). There were significant differences among most landraces regarding their response to the type of salt and salinity levels. Landrace 12 exhibited the highest value of germination percentage under all salt concentrations as compared to other landraces (94.34\%), while landrace 3 recorded the least germination percentage $(87.43 \%)$.

Table (3): Effect of different salt concentrations, landraces and their interaction on germination \%.

\begin{tabular}{|c|c|c|c|c|c|c|c|c|}
\hline \multicolumn{8}{|c|}{ Germination \% } & \multirow[b]{2}{*}{ Mean } \\
\hline Landrace & Control & $\begin{array}{c}5 \mathrm{dSm}^{-1} \\
\mathrm{NaCl}\end{array}$ & $\begin{array}{c}5 \mathrm{dSm}^{-1} \\
\mathrm{CaCl}_{2}\end{array}$ & \multirow{2}{*}{$\begin{array}{c}\mathbf{5} \mathbf{d S m}^{-1} \\
\mathrm{NaCl}^{-\mathrm{CaCl}_{2}} \\
88.78\end{array}$} & $\begin{array}{c}10 \mathrm{dSm}^{-1} \\
\mathrm{NaCl}\end{array}$ & $\begin{array}{c}10 \mathrm{dSm}^{-1} \\
\mathrm{CaCl}_{2}\end{array}$ & $\begin{array}{c}10 \mathrm{dSm}^{-1} \\
\mathrm{NaCl}+\mathrm{CaCl}_{2}\end{array}$ & \\
\hline 1 & 97.35 & 91.51 & 92.53 & & 89.87 & 90.92 & 87.53 & 91.21 \\
\hline 2 & 96.52 & 90.82 & 92.04 & 88.58 & 89.38 & 90.43 & 87.04 & 90.69 \\
\hline 3 & 95.07 & 87.33 & 88.55 & 84.71 & 85.89 & 86.94 & 83.55 & 87.43 \\
\hline 4 & 95.59 & 88.72 & 89.94 & 87.27 & 87.51 & 88.56 & 85.17 & 88.97 \\
\hline 5 & 96.38 & 90.64 & 91.86 & 88.24 & 89.2 & 90.25 & 86.86 & 90.49 \\
\hline 6 & 97.47 & 91.4 & 92.62 & 90.78 & 89.96 & 91.01 & 87.62 & 91.55 \\
\hline 7 & 95.91 & 90.42 & 91.66 & 87.92 & 88.96 & 90.01 & 86.62 & 90.21 \\
\hline 8 & 97.97 & 94.13 & 95.05 & 91.51 & 92.39 & 93.74 & 90.35 & 93.59 \\
\hline 9 & 96.04 & 90.54 & 91.76 & 88.02 & 89.13 & 90.15 & 86.76 & 90.34 \\
\hline 10 & 97.64 & 93.14 & 94.62 & 91.21 & 91.96 & 93.01 & 89.62 & 93.03 \\
\hline 11 & 97.86 & 93.52 & 94.74 & 91.45 & 92.08 & 93.13 & 89.74 & 93.22 \\
\hline 12 & 98.97 & 94.63 & 95.95 & 92.38 & 93.35 & 94.24 & 90.85 & 94.34 \\
\hline 13 & 97.14 & 91.31 & 92.52 & 88.71 & 89.83 & 90.93 & 87.56 & 91.14 \\
\hline 14 & 96.81 & 90.97 & 92.19 & 88.68 & 89.53 & 90.58 & 87.19 & 90.85 \\
\hline 15 & 95.73 & 89.89 & 91.11 & 87.78 & 88.45 & 89.5 & 86.11 & 89.8 \\
\hline 16 & 96.94 & 91.2 & 92.42 & 88.69 & 89.76 & 90.81 & 87.42 & 91.03 \\
\hline 17 & 98.02 & 94.15 & 95.35 & 91.55 & 92.73 & 93.44 & 90.05 & 93.61 \\
\hline Mean & 96.91 & 91.43 & 92.641 & 89.191 & 89.998 & 91.0 & 87.651 & \\
\hline L.S.D ${ }_{5 \%}$ & Landrace & .614 & alt conc & ions $=0.702$ & & tion $=0.9$ & & \\
\hline
\end{tabular}


The data showed that the maximum germination \% values were achieved by the control treatment, while increasing sodium chloride, calcium chloride or their mixture concentrations led to significant decreases in germination percentages overall genotypes. Monirifar (2008), Bhardwaj et al. (2010), Yarnia (2011) and Torabi et al. (2011), reported similar results. Maas and Hoffman (1977) reported that under saline conditions, germination ability of seeds differs from crop to crop, and even a significant variation is observed amongst the different varieties of the same crop.

Germination percentage for all landraces at 5 and $10 \mathrm{dSm}^{-1} \mathrm{NaCl}$ concentrations was less than germination percentage at 5 and $10 \mathrm{dSm}^{-1} \mathrm{CaCl}_{2}$ concentrations, which may be due to the toxic effect of accumulated ions of this salt on the embryonic activity (Khan et al., 1997).

The maximum reduction in germination percentage was observed at $5 \mathrm{dSm}^{-1}$ and $10 \mathrm{dSm}^{-}$ ${ }^{1}$ concentrations of $\mathrm{NaCl}+\mathrm{CaCl}_{2}$ solution being $89.19 \%$ and $87.65 \%$, respectively, and was also observed in the interaction between the landraces and salt concentrations, where landrace 3 recorded $84.71 \%$ and $83.55 \%$ at the same previous concentrations, respectively. The results revealed that $\mathrm{NaCl}+\mathrm{CaCl}_{2}$ mixture act as a stronger inhibitor for the germination of the plant as compared to individual salt stress.

\subsubsection{Plumule length}

Results of plumule length (Table 4) revealed that the landrace 3 exhibited the most decrease and showing significant decrease under all salt treatments, while landrace 12 exhibited positive and significant difference compared to all genotypes under all salt treatments.

The results also revealed that increasing the concentration of sodium chloride salt from 5 to $10 \mathrm{dSm}^{-1}$ led to a significant decrease in plumule length. Also, there was significant difference between the same two concentrations of calcium chloride salt and the effect of mixture of them was more prominent as compared to the effect of individual salt.

The highest value of plumule length was observed by landrace 12 when seeds were wetted with the tap water; it scored $11.04 \mathrm{~cm}$, while the least value was recorded at $10 \mathrm{dSm}^{-1} \mathrm{NaCl}+$ $\mathrm{CaCl}_{2}$ concentration being $1.67 \mathrm{~cm}$ for plumule length.

\subsubsection{Radicle length}

Alfalfa landraces showed a significant reduction in radicle length in all salts concentrations (Table 5). The maximum reduction in radicle length has been recorded in $10 \mathrm{dSm}^{-1}$ concentration of mixture of salts, which was $0.49 \mathrm{~cm}$ compared to $2.12 \mathrm{~cm}$ in control, while the least effect on radicle length was noted at $5 \mathrm{dSm}^{-1}$ of $\mathrm{CaCl}_{2}(4.46 \mathrm{~cm})$ of salt treatments, compared to the control in landrace12. Hamdi and Safarnejad (2010) also reported similar results on alfalfa at salinity stress condition. Salinity is the most important abiotic factor and badly affects seeds germination and radicle elongations of seedlings (Katembe et al., 1998). Increasing salt concentrations dramatically affect both seedling emergence and growth of sunflower (Turhan and Ayaz, 2004).

From the previous data, the two landraces of alfalfa No.12 (salt-tolerant $=\mathrm{L}_{12}$ ) and No.3 (saltsensitive $=L_{3}$ ) were chosen based on screening in lab experiment.

\subsection{Greenhouse experiment}

The results for plant height $(\mathrm{cm})$, root dry weight (g/plant), leaf/stem ratio and dry matter yield $(\mathrm{g} / \mathrm{pot})$ for the two alfalfa landraces under salt treatments combined over two seasons are presented in Tables (6 and 7).

\subsubsection{Plant height $(\mathrm{cm})$}

The data presented in Table (6) showed that $\mathrm{L}_{3}$ and $\mathrm{L}_{12}$ significantly differed in plant height through four cuts and mean. Data revealed that $\mathrm{L}_{12}$ was superior to $\mathrm{L}_{3}$ under salt treatments regarding all cuts. Also, the data showed that plant height decreased under all the treatments of different salts. The maximum reduction in plant height was observed in $10 \mathrm{dSm}^{-1}$ concentration of $\mathrm{NaCl}+\mathrm{CaCl}_{2}$ solution that ranked in means $17.68 \mathrm{~cm}$, while the control treatment revealed the highest value $34.82 \mathrm{~cm}$. The effect of the interaction between salt treatments was significant on investigated traits. The effect of the interaction between two landraces and salt concentrations was significant. The shortest plant height was recorded by $\mathrm{L}_{3}$ when it is grown under $10 \mathrm{dSm}^{1} \mathrm{NaCl}+\mathrm{CaCl}_{2}$. Yusefi et al. (2017) who found that increasing salt concentration caused reduction in plant height obtained same result.

\subsubsection{Root dry weight (g/plant)}

Data in Table (6) showed great variation among the two tested landraces with respect to root dry weight. Furthermore, the tested salinity levels significantly affected root dry weight. Increasing salinity level up to $10 \mathrm{dSm}^{-1}$ for all salts significantly declined gradually root dry weight. A gradual reduction in root dry weight 
Nahid A. A. Morsi et al., .......................................................................

Table (4): Effect of different salt concentrations, landraces and their interaction on plumule length.

\begin{tabular}{|c|c|c|c|c|c|c|c|c|}
\hline \multicolumn{8}{|c|}{ Plumule length $(\mathrm{cm})$} & \multirow{2}{*}{ Mean } \\
\hline Landrace & Control & $\begin{array}{c}5 \mathrm{dSm}^{-1} \\
\mathrm{NaCl}\end{array}$ & $\begin{array}{c}5 \mathrm{dSm}^{-1} \\
\mathrm{CaCl}_{2}\end{array}$ & $\begin{array}{c}5 \mathrm{dSm}^{-1} \\
\mathrm{NaCl}+\mathrm{CaCl}_{2}\end{array}$ & $\begin{array}{c}10 \mathrm{dSm}^{-1} \\
\mathrm{NaCl}\end{array}$ & $\begin{array}{c}10 \mathrm{dSm}^{-1} \\
\mathrm{CaCl}_{2}\end{array}$ & $\begin{array}{c}10 \mathrm{dSm}^{-1} \\
\mathrm{NaCl}+\mathrm{CaCl}_{2}\end{array}$ & \\
\hline 1 & 8.73 & 6.54 & 7.07 & 4.65 & 5.09 & 6.38 & 3.87 & 6.05 \\
\hline 2 & 8.23 & 5.67 & 6.28 & 3.78 & 4.23 & 5.51 & 3.09 & 5.26 \\
\hline 3 & 6.88 & 4.25 & 4.98 & 2.36 & 2.86 & 4.09 & 1.67 & 3.87 \\
\hline 4 & 7.31 & 4.92 & 5.63 & 3.01 & 3.45 & 4.74 & 2.32 & 4.48 \\
\hline 5 & 7.98 & 5.55 & 6.35 & 3.66 & 4.22 & 5.39 & 2.97 & 5.16 \\
\hline 6 & 8.74 & 6.75 & 7.27 & 4.65 & 5.31 & 6.59 & 4.17 & 6.21 \\
\hline 7 & 7.53 & 5.33 & 6.06 & 3.44 & 3.68 & 5.17 & 2.75 & 4.85 \\
\hline 8 & 10.17 & 8.09 & 9.22 & 6.33 & 6.74 & 8.03 & 5.61 & 7.74 \\
\hline 9 & 7.87 & 5.38 & 6.11 & 3.49 & 3.93 & 5.22 & 2.86 & 4.98 \\
\hline 10 & 9.74 & 7.48 & 7.76 & 5.87 & 6.01 & 7.31 & 5.18 & 7.05 \\
\hline 11 & 9.81 & 7.83 & 8.56 & 5.94 & 6.38 & 7.67 & 5.27 & 7.35 \\
\hline 12 & 11.04 & 9.06 & 9.79 & 7.37 & 7.79 & 9.01 & 6.52 & 8.65 \\
\hline 13 & 8.65 & 6.34 & 6.65 & 4.89 & 5.88 & 6.18 & 3.78 & 6.05 \\
\hline 14 & 8.32 & 5.76 & 6.49 & 3.87 & 4.31 & 5.64 & 3.18 & 5.37 \\
\hline 15 & 7.36 & 5.01 & 5.73 & 3.11 & 3.55 & 4.84 & 2.42 & 4.57 \\
\hline 16 & 8.52 & 5.89 & 6.62 & 3.97 & 4.44 & 5.73 & 3.31 & 5.5 \\
\hline 17 & 10.37 & 8.29 & 8.92 & 6.64 & 7.04 & 8.37 & 5.91 & 7.93 \\
\hline Mean & 8.38 & 6.38 & 7.01 & 4.53 & 4.99 & 6.23 & 3.82 & \\
\hline L.S.D ${ }_{5 \%}$ & \multicolumn{8}{|c|}{ Landraces $=0.392$} \\
\hline
\end{tabular}

was observed in the four cuts and mean at 10 $\mathrm{dSm}^{-1}$ of $\mathrm{NaCl}+\mathrm{CaCl}_{2}$ mixture that was 0.18 , $0.4,0.94,0.62$ and 0.55 , respectively. It is clear that root dry weight is badly affected in all the concentrations of combined salts of $\mathrm{NaCl}$ and $\mathrm{CaCl}_{2}$. The maximum mean reduction of interaction was showed by $\mathrm{L}_{3}$ with $10 \mathrm{dsm}^{-1}$ $\mathrm{NaCl}+\mathrm{CaCl}_{2}$ concentration $(68.0 \%)$. These results could be explained by the findings of Helmy et al. (2003) who stated that reduction in dry root weight varied according to the different concentrations of salt.

\subsubsection{Leaf/ stem ratio}

From the data in Table (7), it was found that $\mathrm{L}_{12}$ was higher than $\mathrm{L}_{3}$ in leaf/stem ratio trait. The harmful influence on leaf/stem ratio was increased with increasing salt levels (Table 7). There are significant differences between the two landraces under study in means of four cuts that revealed 1.06 and 0.67 , respectively. The effect of mixture of salts on leaf/stem ratio was more prominent compared to the effect of individual salt. For $10 \mathrm{dSm}^{-1} \mathrm{NaCl}+\mathrm{CaCl}_{2}$ concentration leaf/stem ratio was recorded to be $0.7,0.58,0.42,0.2$ and 0.47 for four cuts and mean, respectively. The minimum mean reduction for leaf/stem ratio at $5 \mathrm{dSm}^{-1}$ of $\mathrm{CaCl}_{2}$ concentration was recorded $(30.20 \%)$. The interaction effect between landraces and salt concentrations significantly influenced leaf/stem ratio. Results indicated that the highest values of leaf/stem ratio were obtained by $\mathrm{L}_{12}$ in control treatment followed by $\mathrm{L}_{3}$ in the same treatment. These results are in agreement with Torabi et al. (2011) who found that increasing of salt concentration led to decrease in leaf/stem ratio of alfalfa.

\subsubsection{Dry matter yield (g/pot)}

Results in Table (7) showed that both $\mathrm{L}_{3}$ and $\mathrm{L}_{12}$ significantly differed in plant height through four cuts and mean. Data revealed that total dry matter yield of landrace $\left(\mathrm{L}_{12}\right)$ was more superior to the other landrace $\left(\mathrm{L}_{3}\right)$ under salt treatments regarding all cuts by 34.80 and $22.17 \mathrm{~g} / \mathrm{pot}$, respectively. The data also showed that total dry matter yield decreased under all the treatments 
Table (5): Effect of different salt concentrations, landraces and their interaction on radicle length.

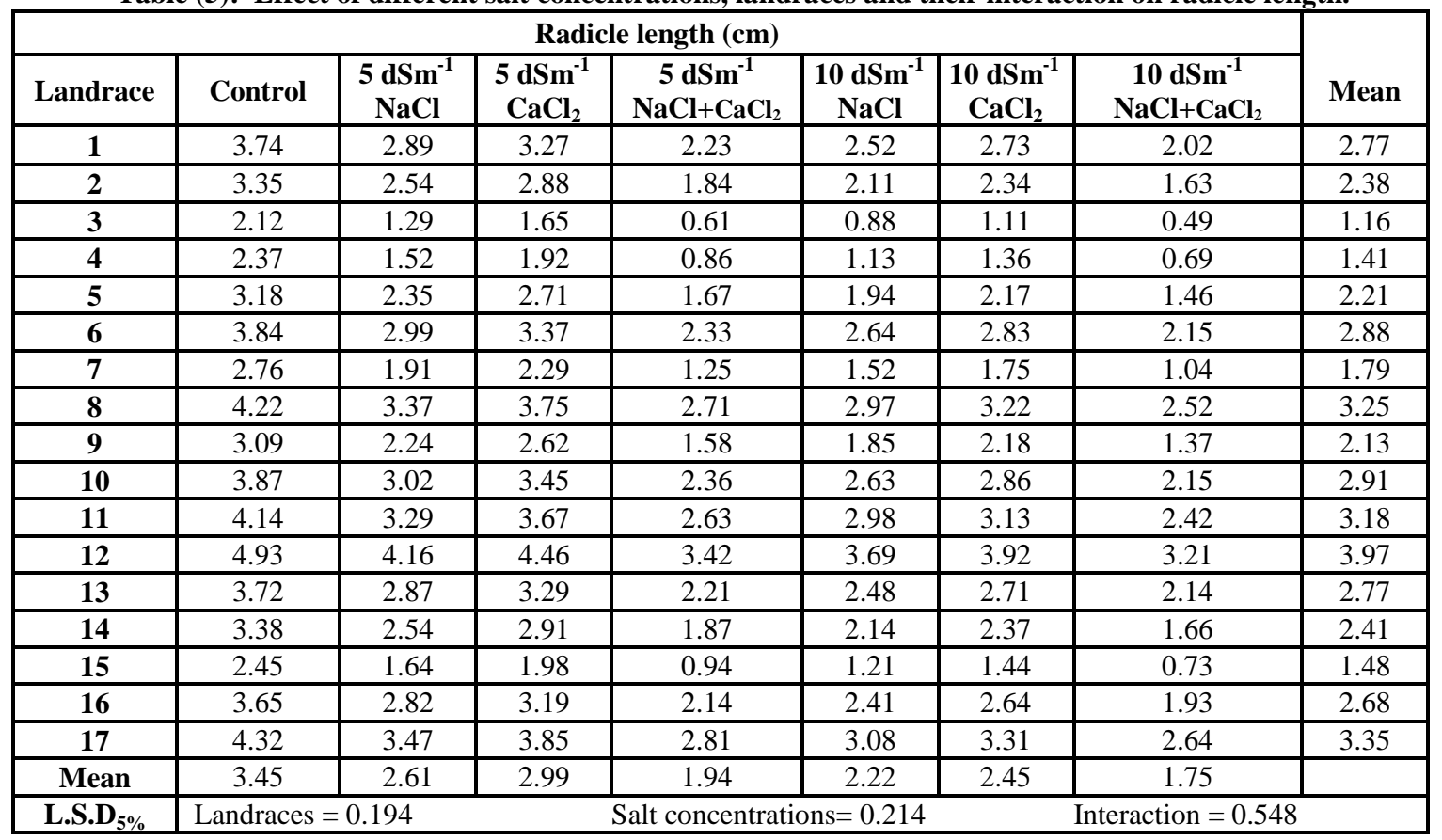

Table (6): Effect of landraces, salt treatments and their interaction on plant height $(\mathrm{cm})$ and root dry weight $(\mathrm{g} / \mathrm{plant})$ traits (combined of two seasons).

\begin{tabular}{|c|c|c|c|c|c|c|c|c|c|c|}
\hline \multirow[b]{2}{*}{ Treatments } & \multicolumn{5}{|c|}{ Plant height (cm) } & \multicolumn{5}{|c|}{ Root dry weight (g/plant) } \\
\hline & $1^{s t}$ cut & $2^{\text {nd }}$ cut & $3^{\text {rd }}$ cut & $4^{\text {th }}$ cut & Mean & $1^{s t}$ cut & $2^{\text {nd }}$ cut & $3^{\text {rd }}$ cut & $4^{\text {th }}$ cut & Mean \\
\hline \multicolumn{11}{|c|}{ Landraces } \\
\hline The most tolerant $\left(\mathrm{L}_{12}\right)$ & 29.46 & 31.58 & 25.9 & 24.33 & 27.82 & 0.62 & 0.87 & 1.39 & 1.13 & 1.01 \\
\hline The most sensitive $\left(\mathrm{L}_{3}\right)$ & 26.62 & 28.74 & 23.06 & 21.49 & 24.98 & 0.4 & 0.63 & 1.16 & 0.91 & 0.78 \\
\hline F- test & $* *$ & $* *$ & $* *$ & $* *$ & $* *$ & $* *$ & $* *$ & $* *$ & $* *$ & $* *$ \\
\hline \multicolumn{11}{|c|}{ Salt treatments } \\
\hline Control $\left(T_{1}\right)$ & 36.46 & 38.58 & 32.9 & 31.33 & 34.82 & 1.02 & 1.25 & 1.78 & 1.46 & 1.4 \\
\hline $5 \mathrm{dSm}^{-1} \mathrm{NaCl}\left(\mathrm{T}_{2}\right)$ & 30.75 & 32.87 & 27.19 & 25.62 & 29.11 & 0.58 & 0.81 & 1.34 & 1.02 & 0.96 \\
\hline $5 \mathrm{dSm}^{-1} \mathrm{CaCl}_{2}\left(\mathrm{~T}_{3}\right)$ & 32.62 & 34.74 & 29.06 & 27.49 & 30.98 & 0.72 & 0.95 & 1.43 & 1.15 & 1.09 \\
\hline $5 \mathrm{dSm}^{-1} \mathrm{NaCl}+\mathrm{CaCl}_{2}\left(\mathrm{~T}_{4}\right)$ & 22.53 & 24.65 & 18.97 & 17.4 & 20.89 & 0.25 & 0.48 & 1.06 & 0.71 & 0.64 \\
\hline $10 \mathrm{dSm}^{-1} \mathrm{NaCl}\left(\mathrm{T}_{5}\right)$ & 25.83 & 27.95 & 22.27 & 20.7 & 24.19 & 0.38 & 0.61 & 1.14 & 0.82 & 0.76 \\
\hline $10 \mathrm{dSm}^{-1} \mathrm{CaCl}_{2}\left(\mathrm{~T}_{6}\right)$ & 28.81 & 30.93 & 25.25 & 23.68 & 27.16 & 0.46 & 0.75 & 1.22 & 0.92 & 0.86 \\
\hline $10 \mathrm{dSm}^{-1} \mathrm{NaCl}+\mathrm{CaCl}_{2}\left(\mathrm{~T}_{7}\right)$ & 19.32 & 21.44 & 15.76 & 14.19 & 17.68 & 0.18 & 0.4 & 0.94 & 0.62 & 0.55 \\
\hline L.S.D $5 \%$ & 1.53 & 1.36 & 1.65 & 1.92 & 2.15 & 0.31 & 0.23 & 0.19 & 0.20 & 0.26 \\
\hline \multicolumn{11}{|c|}{ Interactions } \\
\hline $\mathbf{L}_{12} \times \mathbf{T}_{1}$ & 37.74 & 39.86 & 34.18 & 32.61 & 36.1 & 1.12 & 1.35 & 1.88 & 1.63 & 1.5 \\
\hline $\mathbf{L}_{12} \times T_{2}$ & 32.39 & 34.51 & 28.83 & 27.26 & 30.75 & 0.73 & 0.96 & 1.49 & 1.24 & 1.11 \\
\hline $\mathbf{L}_{12} \times T_{3}$ & 34.78 & 36.9 & 31.22 & 29.65 & 33.14 & 0.91 & 1.14 & 1.58 & 1.42 & 1.27 \\
\hline $\mathbf{L}_{12} \times T_{4}$ & 24.21 & 26.33 & 20.65 & 19.08 & 22.57 & 0.31 & 0.54 & 1.17 & 0.82 & 0.71 \\
\hline $\mathbf{L}_{12} \times \mathbf{T}_{5}$ & 26.11 & 28.23 & 22.55 & 20.98 & 24.47 & 0.46 & 0.69 & 1.22 & 0.98 & 0.84 \\
\hline $\mathbf{L}_{12} \times \mathrm{T}_{6}$ & 29.93 & 32.05 & 26.37 & 24.8 & 28.28 & 0.58 & 0.93 & 1.34 & 1.09 & 0.99 \\
\hline $\mathbf{L}_{12} \times \mathbf{T}_{7}$ & 21.09 & 23.21 & 17.53 & 15.96 & 19.45 & 0.23 & 0.46 & 1.02 & 0.74 & 0.62 \\
\hline $\mathbf{L}_{3} \times \mathbf{T}_{1}$ & 35.18 & 37.3 & 31.62 & 30.05 & 33.54 & 0.91 & 1.14 & 1.67 & 1.42 & 1.29 \\
\hline $\mathrm{L}_{3} \times \mathrm{T}_{2}$ & 29.1 & 31.22 & 25.54 & 23.97 & 27.46 & 0.42 & 0.65 & 1.18 & 0.93 & 0.8 \\
\hline$L_{3} \times T_{3}$ & 30.45 & 32.57 & 26.89 & 25.32 & 28.81 & 0.52 & 0.75 & 1.28 & 1.03 & 0.9 \\
\hline $\mathbf{L}_{3} \times \mathbf{T}_{4}$ & 20.84 & 22.96 & 17.28 & 15.71 & 19.2 & 0.19 & 0.42 & 0.95 & 0.71 & 0.57 \\
\hline $\mathbf{L}_{3} \times T_{5}$ & 25.54 & 27.66 & 21.98 & 20.41 & 23.9 & 0.29 & 0.52 & 1.05 & 0.8 & 0.67 \\
\hline $\mathrm{L}_{3} \times \mathrm{T}_{6}$ & 27.68 & 29.8 & 24.12 & 22.55 & 26.04 & 0.34 & 0.57 & 1.1 & 0.85 & 0.72 \\
\hline $\mathbf{L}_{3} \times \mathbf{T}_{7}$ & 17.54 & 19.66 & 13.98 & 12.41 & 15.9 & 0.12 & 0.33 & 0.86 & 0.61 & 0.48 \\
\hline L.S.D $5 \%$ & 1.84 & 1.92 & 2.16 & 3.53 & 2.66 & 0.28 & 0.20 & 0.19 & 0.32 & 0.25 \\
\hline
\end{tabular}


Nahid A. A. Morsi et al., ........................................................................

Table (7): Effect of landraces, salt treatments and their interaction on leaf/stem ratio and dry matter yield (g/pot) traits (combined of two seasons).

\begin{tabular}{|c|c|c|c|c|c|c|c|c|c|c|}
\hline \multirow[b]{2}{*}{ Treatments } & \multicolumn{5}{|c|}{ Leaf/stem ratio } & \multicolumn{5}{|c|}{ Dry matter yield (g/pot) } \\
\hline & $1^{\text {st }}$ cut & $2^{\text {nd }}$ cut & $3^{r d}$ cut & $4^{\text {th }}$ cut & Mean & $1^{\text {st }}$ cut & $2^{\text {nd }}$ cut & $3^{\text {rd }}$ cut & $4^{\text {th }}$ cut & Total \\
\hline \multicolumn{11}{|c|}{ landraces } \\
\hline The most tolerant $\left(\mathrm{L}_{12}\right)$ & 0.66 & 1.01 & 1.13 & 1.44 & 1.06 & 6.3 & 8.4 & 9.32 & 10.78 & 34.8 \\
\hline The most sensitive $\left(\mathrm{L}_{3}\right)$ & 0.51 & 0.6 & 0.8 & 0.74 & 0.67 & 3.56 & 5.11 & 6.01 & 7.5 & 22.17 \\
\hline F- test & $* *$ & $* *$ & $* *$ & $* *$ & *** & $* *$ & $* *$ & *** & $* *$ & $* *$ \\
\hline \multicolumn{11}{|c|}{ Salt treatments } \\
\hline Control $\left(\mathbf{T}_{1}\right)$ & 1.19 & 1.45 & 1.6 & 1.73 & 1.49 & 9.63 & 11.65 & 12.64 & 14.1 & 48.00 \\
\hline $5 \mathrm{dSm}^{-1} \mathrm{NaCl}\left(\mathrm{T}_{2}\right)$ & 0.67 & 0.88 & 1.04 & 1.17 & 0.94 & 6.31 & 8.55 & 9.32 & 10.78 & 34.96 \\
\hline $5 \mathrm{dSm}^{-1} \mathrm{CaCl}_{2}\left(\mathrm{~T}_{3}\right)$ & 0.76 & 0.97 & 1.16 & 1.28 & 1.04 & 7.45 & 9.48 & 10.34 & 11.93 & 39.20 \\
\hline $5 \mathrm{dSm}^{-1} \mathrm{NaCl}+\mathrm{CaCl}_{2}\left(\mathrm{~T}_{4}\right)$ & 0.32 & 0.53 & 0.69 & 0.81 & 0.59 & 2.1 & 3.56 & 4.55 & 6.01 & 16.20 \\
\hline $10 \mathrm{dSm}^{-1} \mathrm{NaCl}\left(\mathrm{T}_{5}\right)$ & 0.41 & 0.62 & 0.78 & 0.91 & 0.68 & 2.88 & 4.83 & 5.82 & 7.29 & 20.82 \\
\hline $10 \mathrm{dSm}^{-1} \mathrm{CaCl}_{2}\left(\mathrm{~T}_{6}\right)$ & 0.55 & 0.76 & 0.92 & 1.06 & 0.83 & 5.23 & 7.3 & 8.28 & 9.74 & 30.55 \\
\hline $10 \mathrm{dSm}^{-1} \mathrm{NaCl}+\mathrm{CaCl}_{2}\left(\mathrm{~T}_{7}\right)$ & 0.2 & 0.42 & 0.58 & 0.7 & 0.47 & 0.93 & 1.93 & 2.7 & 4.16 & 9.72 \\
\hline L.S.D $5 \%$ & 0.08 & 0.08 & 0.09 & 0.10 & 0.09 & 1.76 & 1.82 & 2.14 & 2.01 & 2.99 \\
\hline \multicolumn{11}{|c|}{ Interactions } \\
\hline $\mathrm{L}_{12} \times \mathrm{T}_{1}$ & 1.28 & 1.62 & 1.73 & 2.04 & 1.67 & 10.85 & 12.87 & 13.86 & 15.32 & 52.9 \\
\hline $\mathbf{L}_{12} \times \mathbf{T}_{2}$ & 0.75 & 1.09 & 1.21 & 1.52 & 1.14 & 7.98 & 10.43 & 10.99 & 12.45 & 41.85 \\
\hline $\mathrm{L}_{12} \times \mathrm{T}_{3}$ & 0.84 & 1.18 & 1.35 & 1.66 & 1.26 & 9.04 & 11.06 & 12.05 & 13.51 & 45.66 \\
\hline $\mathbf{L}_{12} \times T_{4}$ & 0.36 & 0.7 & 0.82 & 1.13 & 0.76 & 2.96 & 4.98 & 5.97 & 7.43 & 21.34 \\
\hline $\mathbf{L}_{12} \times \mathrm{T}_{5}$ & 0.49 & 0.83 & 0.95 & 1.26 & 0.88 & 4.76 & 6.78 & 7.77 & 9.23 & 28.54 \\
\hline $\mathbf{L}_{12} \times T_{6}$ & 0.63 & 0.96 & 1.09 & 1.42 & 1.03 & 7.32 & 9.45 & 10.41 & 11.87 & 39.05 \\
\hline $\mathbf{L}_{12} \times \mathrm{T}_{7}$ & 0.28 & 0.62 & 0.74 & 1.05 & 0.67 & 1.21 & 3.22 & 4.21 & 5.67 & 14.31 \\
\hline $\mathbf{L}_{3} \times \mathbf{T}_{1}$ & 1.09 & 1.27 & 1.47 & 1.41 & 1.31 & 8.4 & 10.42 & 11.41 & 12.87 & 43.1 \\
\hline $\mathrm{L}_{3} \times \mathrm{T}_{2}$ & 0.59 & 0.67 & 0.87 & 0.81 & 0.74 & 4.64 & 6.66 & 7.65 & 9.11 & 28.06 \\
\hline $\mathbf{L}_{3} \times \mathbf{T}_{3}$ & 0.68 & 0.76 & 0.96 & 0.89 & 0.82 & 5.87 & 7.89 & 8.63 & 10.34 & 32.73 \\
\hline $\mathbf{L}_{3} \times \mathbf{T}_{4}$ & 0.27 & 0.35 & 0.55 & 0.49 & 0.42 & 1.23 & 2.13 & 3.12 & 4.58 & 11.06 \\
\hline $\mathbf{L}_{3} \times \mathbf{T}_{5}$ & 0.33 & 0.41 & 0.61 & 0.55 & 0.48 & 0.99 & 2.89 & 3.88 & 5.34 & 13.1 \\
\hline $\mathrm{L}_{3} \times \mathrm{T}_{6}$ & 0.47 & 0.55 & 0.75 & 0.69 & 0.62 & 3.14 & 5.16 & 6.15 & 7.61 & 22.06 \\
\hline $\mathbf{L}_{3} \times \mathbf{T}_{7}$ & 0.12 & 0.22 & 0.41 & 0.34 & 0.27 & 0.65 & 0.63 & 1.19 & 2.65 & 5.12 \\
\hline L.S.D $5 \%$ & 0.14 & 0.17 & 0.21 & 0.19 & 0.21 & 2.04 & 2.12 & 1.94 & 1.98 & 3.87 \\
\hline
\end{tabular}

of different salts, the lowest value was observed in $10 \mathrm{dSm}^{-1}$ concentration of $\mathrm{NaCl}+\mathrm{CaCl}_{2}$ solution $9.72 \mathrm{~g} / \mathrm{plot}$, while control treatment revealed the highest value through four cuts followed by $5 \mathrm{dSm}^{-1} \mathrm{CaCl}_{2}$ treatment (48.00 and $39.20 \mathrm{~g} / \mathrm{pot}$ ), respectively.

The combination of $\mathrm{L}_{12}$ and the control treatment had maximum value of total dry matter $(52.9 \mathrm{~g} / \mathrm{plot})$ followed by the interaction between the same landrace with $\mathrm{T}_{3}$ whereas a significant decrease of dry matter yield was observed for the same landrace with $10 \mathrm{dSm}^{-1} \mathrm{NaCl}+\mathrm{CaCl}_{2}$ treatment $\left(\mathrm{T}_{7}\right)$ concentration that recorded the highest reduction but with $\mathrm{L}_{3}(5.12 \mathrm{~g} / \mathrm{pot})$. Monirifar et al. (2004) reported the presence of phenotypic variation between some alfalfa cultivars at different salinity levels and reduction in forage yield resulting under saline stress.

\subsection{Isozymes molecular marker}

The most tolerant and sensitive landraces of alfalfa were adopted in this investigation to detect markers for salt tolerance. The banding patterns appeared with the three isozymes, i.e. peroxidase (POX), Polyphenyl Oxidase (PPO) and alcohol dehydrogenase $(\mathrm{ADH})$, revealed wide variation of different bands (Fig. 1). Polyphenyl Oxidase was the highest polymorphic isozymes giving rise to 11 bands while Peroxidase and alcohol dehydrogenase gave rise to 10 bands.

\subsubsection{Peroxidase (POX)}

The POX isozyme activity showed up to ten distinct polymorphic bands (Fig. 1A and Table 8). The activity of isozymes (band intensity) increased under the tolerant landrace compared with the sensitive landrace.

In salt tolerant landrace, a new band was detected at all $5 \mathrm{dSm}^{-1} \mathrm{NaCl}, 5 \mathrm{dSm}^{-1} \mathrm{NaCl}+$ $\mathrm{CaCl}_{2}$ and $10 \mathrm{dSm}^{-1} \mathrm{CaCl}_{2}$ in the tolerant landrace, whereas another a new band appeared with treatments $5 \mathrm{dSm}^{-1} \mathrm{CaCl}_{2}, 10 \mathrm{dSm}^{-1} \mathrm{NaCl}$ and $10 \mathrm{dSm}^{-1} \mathrm{NaCl}+\mathrm{CaCl}_{2}$ (bands no. 4 and 6) 
T1 T2 T3 T4 T5 T6 T7 $\quad$ S1 $\quad$ S2 53 S4 S5 $56 \quad$ S7

\section{Peroxidase}

$\mathbf{A}$

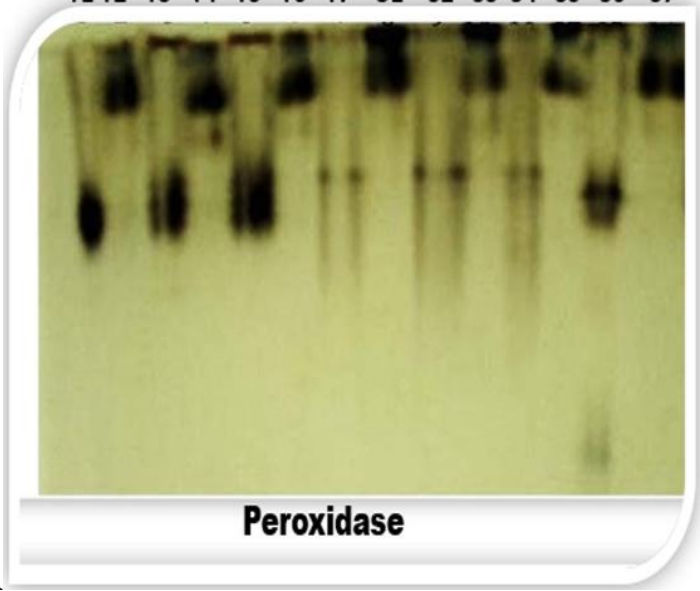

B

Polyphenol oxidase (PPO)

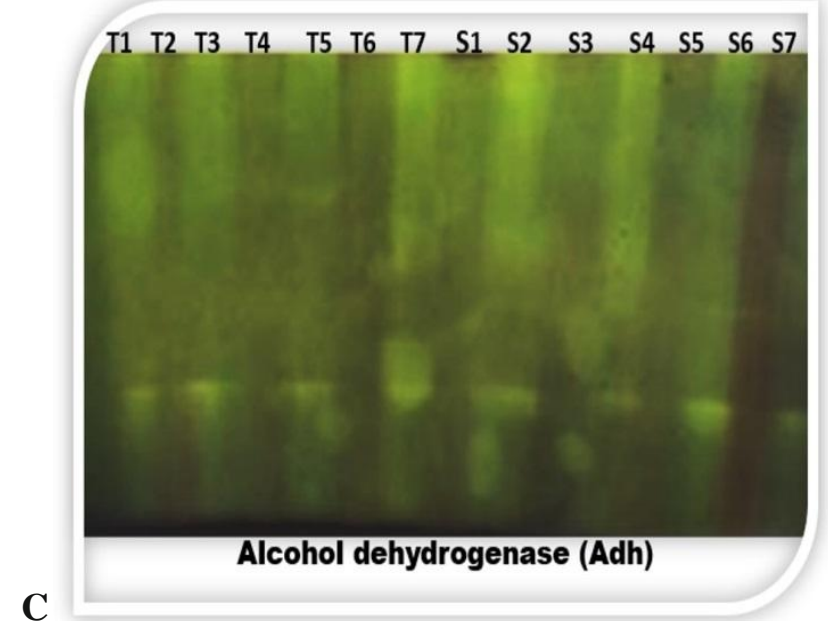

Fig. (1): Banding pattern of (A) peroxidase (POX), (B) Poly Phenyl Oxidase (PPO) and (C) Alcohol Dehydrogenase (ADH) in normal and salinity stress for two alfalfa landraces.

Whereas,

$\mathrm{T} 1=$ The most tolerant landrace under control

$\mathrm{T} 2=$ The most tolerant landrace under $5 \mathrm{dSm}-{ }^{1} \mathrm{NaCl}$

$\mathrm{T} 3=$ The most tolerant landrace under $5 \mathrm{dSm}-{ }^{1} \mathrm{CaCl}_{2}$

T4=The most tolerant landrace under $5 \mathrm{dSm}^{-1} \mathrm{NaCl}+\mathrm{CaCl}_{2}$

T5=The most tolerant landrace under $10 \mathrm{dSm}-{ }^{1} \mathrm{NaCl}$

$\mathrm{T} 6=$ The most tolerant landrace under $10 \mathrm{dSm}^{-1} \mathrm{CaCl}_{2}$

$\mathrm{T} 7=$ The most tolerant landrace under $10 \mathrm{dSm}-{ }^{1} \mathrm{NaCl}^{+} \mathrm{CaCl}_{2}$
$\mathrm{S} 1=$ The most sensitive landrace under control

$\mathrm{S} 2=$ The most sensitive landrace under $5 \mathrm{dSm}-{ }^{1} \mathrm{NaCl}$

$\mathrm{S} 3=$ The most sensitive landrace under $5 \mathrm{dSm}-{ }^{1} \mathrm{CaCl}_{2}$

$\mathrm{S} 4=$ The most sensitive landrace under $5 \mathrm{dSm}-{ }^{1} \mathrm{NaCl}+\mathrm{CaCl}_{2}$

S5 $=$ The most sensitive landrace under $10 \mathrm{dSm}^{-1} \mathrm{NaCl}$

S6 $=$ The most sensitive landrace under $10 \mathrm{dSm}^{-1} \mathrm{CaCl}_{2}$

Table (8): Peroxidase isozyme banding patterns for salt treatments in tolerant and sensitive landraces under study.

\begin{tabular}{|l|c|c|c|c|c|c|c|c|c|c|c|c|c|c|}
\hline Band no. & $\mathbf{T}_{\mathbf{1}}$ & $\mathbf{T}_{\mathbf{2}}$ & $\mathbf{T}_{\mathbf{3}}$ & $\mathbf{T}_{\mathbf{4}}$ & $\mathbf{T}_{\mathbf{5}}$ & $\mathbf{T}_{\mathbf{6}}$ & $\mathbf{T}_{\mathbf{7}}$ & $\mathbf{S}_{\mathbf{1}}$ & $\mathbf{S}_{\mathbf{2}}$ & $\mathbf{S}_{\mathbf{3}}$ & $\mathbf{S}_{\mathbf{4}}$ & $\mathbf{S}_{\mathbf{5}}$ & $\mathbf{S}_{\mathbf{6}}$ & $\mathbf{S}_{\mathbf{7}}$ \\
\hline $\mathbf{1}$ & + & + & + & + & + & + & + & + & + & + & + & + & + & + \\
\hline $\mathbf{2}$ & - & + & + & + & + & + & - & + & - & + & - & - & - & + \\
\hline $\mathbf{3}$ & - & + & - & + & - & + & - & + & - & + & - & + & - & + \\
\hline $\mathbf{5}$ & - & + & - & + & - & + & - & - & - & - & - & - & - & - \\
\hline $\mathbf{6}$ & - & - & - & - & - & - & - & - & - & - & - & - & - & - \\
\hline $\mathbf{7}$ & - & - & + & - & + & - & + & - & - & - & - & - & - & - \\
\hline $\mathbf{8}$ & + & - & + & - & + & - & - & - & + & - & + & - & + & - \\
\hline $\mathbf{9}$ & + & - & + & - & + & - & - & - & - & - & - & - & + & - \\
\hline $\mathbf{1 0}$ & + & - & + & - & + & & - & - & - & - & - & - & + & - \\
\hline
\end{tabular}

(+) presence of band

(-) absence of band 
respectively. Thus, these bands can be used as positive molecular markers for salinity tolerance in alfalfa plants. In sensitive landrace, the activity of bands increased under stress compared with control. These results are in agreement with Yusefi et al. (2017) who reported that salt stress increased the activities of peroxidase levels in alfalfa and Azzam et al. (2012) in Fahl berseem. In addition, Rashed et al. (1994) observed occurrence of different response in activity of intensity rather that in the isoforms of peroxidase in favor of salt tolerant genotypes under stress.

\subsubsection{Polyphenyl oxidase (PPO)}

The results of total poly phenyl oxidase activity gave eleven polymorphic bands (Figure $1 \mathrm{~B}$ and Table 9). The new band appeared at both of $5 \mathrm{dSm}^{-1} \mathrm{CaCl}_{2}$ and $10 \mathrm{dSm}^{-1} \mathrm{NaCl}$. So, these bands can be used as positive molecular markers for salinity tolerance.

In the same direction, banding patterns of the sensitive landrace $\left(\mathrm{L}_{3}\right)$ showed a new band at both of $5 \mathrm{dsm}^{-1} \mathrm{NaCl}$ and $5 \mathrm{dsm}^{-1} \mathrm{NaCl}+\mathrm{CaCl}_{2}$ treatments. So, these bands can be used as negative molecular markers for salinity tolerance. In general, the activity of isozymes (band intensity) increased under salinity. The results of the present investigation are in accordance with those of Abdel-Tawab et al. (2011) who detected significant PPO activity influenced by salt stress compared with control.

\subsubsection{Alcohol dehydrogenase (ADH)}

The major variations are expressed as changes in appearance or disappearance of some bands. A total of 10 bands of Alcohol dehydrogenase activity are illustrated in Figure (1C) and Table (10). Under treatments of 5, 10 $\mathrm{dSm}^{-1} \mathrm{NaCl}$ and $5 \mathrm{dSm}^{-1} \mathrm{NaCl}+\mathrm{CaCl}_{2}$, only new band appeared and a new two bands exhibited at both of $10 \mathrm{dSm}^{-1} \mathrm{CaCl}_{2}, 5$ and $10 \mathrm{dSm}^{-1} \mathrm{NaCl}+$ $\mathrm{CaCl}_{2}$ in the tolerant landrace compared with control, whereas in $5 \mathrm{dSm}^{-1} \mathrm{CaCl}_{2}$ was not evident any new bands. So, these bands can be used as positive molecular markers for salinity tolerance. In the sensitive landrace treated with 5, $10 \mathrm{dSm}^{-1} \mathrm{CaCl}_{2}$ and $10 \mathrm{dSm}^{-1} \mathrm{NaCl}+\mathrm{CaCl}_{2}$ did not induce any new bands in this study, but a new band revealed in the other treatments which considered as negative markers compared with control. The differences in gene expression were indicated with $\mathrm{ADH}$ according to the newly synthesized and the disappearance of some bands (Azzam et al., 2012).Wang et al. (2009) studied the effect of salt stress on the activities leaf $\mathrm{ADH}$ in alfalfa and reported significant higher increase in $\mathrm{ADH}$ activity under salt treatment.

In general, the increase of band intensity and appearance of new bands may be an indication of an increase in isozymes activity under salinity conditions. The multiple isoforms of enzymes is one of the primary control mechanisms of cellular metabolism in plants and the change in the isozyme profiles plays an important role in the cellular defense against salt stress (Amal et al., 2010).

Gao et al. (2008) reported that increased isozymes activities might enable plants to protect themselves against salt stress. In fact, some isozymes have been experienced in a numerous cases of stress effects (Saad-Allah, 2015). Moreover, Valizadeh et al. (2013) reported that activity of some isozymes showed positive correlations for salinity stress of alfalfa plant.

Table (9): Poly Phenyl Oxidase isozyme banding patterns for salt treatments in tolerant and sensitive landraces under study.

\begin{tabular}{l|c|c|c|c|c|c|c|c|c|c|c|c|c|c|c|}
\hline Band no. & $\mathbf{T}_{1}$ & $\mathbf{T}_{\mathbf{2}}$ & $\mathbf{T}_{\mathbf{3}}$ & $\mathbf{T}_{\mathbf{4}}$ & $\mathbf{T}_{\mathbf{5}}$ & $\mathbf{T}_{\mathbf{6}}$ & $\mathbf{T}_{\mathbf{7}}$ & $\mathbf{S}_{\mathbf{1}}$ & $\mathbf{S}_{2}$ & $\mathbf{S}_{\mathbf{3}}$ & $\mathbf{S}_{4}$ & $\mathbf{S}_{\mathbf{5}}$ & $\mathbf{S}_{\mathbf{6}}$ & $\mathbf{S}_{7}$ \\
\hline $\mathbf{1}$ & + & + & + & + & + & + & + & + & - & - & - & + & + & + \\
\hline $\mathbf{2}$ & - & - & - & - & - & - & - & - & - & - & - & - & - & - \\
\hline $\mathbf{3}$ & - & - & - & - & - & - & - & - & + & - & + & - & - & - \\
\hline $\mathbf{4}$ & + & + & + & - & - & - & - & + & - & + & - & - & - & - \\
\hline $\mathbf{5}$ & - & - & + & - & + & - & - & - & - & - & - & - & - & - \\
\hline $\mathbf{6}$ & - & - & - & - & + & - & - & - & - & - & - & - & + & - \\
\hline $\mathbf{7}$ & - & - & - & - & - & - & - & - & - & - & - & - & - & - \\
\hline $\mathbf{8}$ & + & - & - & - & - & - & - & - & - & - & - & - & - & - \\
\hline $\mathbf{9}$ & - & - & - & - & + & & - & - & - & - & - & + & - & + \\
\hline $\mathbf{1 0}$ & - & + & - & - & - & + & + & + & - & - & - & - & + & - \\
\hline $\mathbf{1 1}$ & - & + & - & + & - & + & + & - & - & - & - & - & + & + \\
\hline
\end{tabular}


Table (10): Alcohol dehydrogenase isozyme banding patterns for salt treatments in tolerant and sensitive landraces under study.

\begin{tabular}{l|c|c|c|c|c|c|c|c|c|c|c|c|c|c|c|}
\hline Band no. & $\mathbf{T}_{1}$ & $\mathbf{T}_{2}$ & $\mathbf{T}_{3}$ & $\mathbf{T}_{\mathbf{4}}$ & $\mathbf{T}_{\mathbf{5}}$ & $\mathbf{T}_{\mathbf{6}}$ & $\mathbf{T}_{7}$ & $\mathbf{S}_{\mathbf{1}}$ & $\mathbf{S}_{2}$ & $\mathbf{S}_{\mathbf{3}}$ & $\mathbf{S}_{4}$ & $\mathbf{S}_{\mathbf{5}}$ & $\mathbf{S}_{\mathbf{6}}$ & $\mathbf{S}_{7}$ \\
\hline $\mathbf{1}$ & + & + & + & + & + & + & + & + & + & + & + & - & + & - \\
\hline $\mathbf{2}$ & - & - & - & - & - & - & - & - & - & - & - & - & - & - \\
\hline $\mathbf{3}$ & - & - & - & - & - & - & - & - & + & - & + & + & - & - \\
\hline $\mathbf{4}$ & - & + & - & - & + & - & - & - & - & - & - & - & - & - \\
\hline $\mathbf{5}$ & - & - & - & + & - & - & - & - & - & - & - & - & - & - \\
\hline $\mathbf{6}$ & - & - & - & - & - & - & + & - & - & - & - & - & - & - \\
\hline $\mathbf{7}$ & - & - & - & - & - & - & - & - & - & - & - & - & - & - \\
\hline $\mathbf{8}$ & + & - & + & - & + & - & + & - & + & - & + & - & + & + \\
\hline $\mathbf{9}$ & - & - & - & - & - & + & - & - & - & - & - & - & - & - \\
\hline $\mathbf{1 0}$ & - & - & - & - & - & + & + & - & - & - & - & - & - & - \\
\hline
\end{tabular}

\section{Conclusion}

Landrace 12 was superior to landrace 3 in all traits. Sodium chloride had greater effect than calcium chloride stress on alfalfa. In combined salts stress, a marked reduction in all growth parameters at all salt levels was recorded. The most tolerant and the most sensitive alfalfa landraces were assessed to peroxidase (POX), poly phenyl oxidase (PPO) and alcohol dehydrogenase $(\mathrm{ADH})$ systems under different salt concentrations. The POX, PPO and ADH isozyme activities showed up to 10,11 and 10 distinct polymorphic bands, respectively. The activity of isozymes (band intensity) increased under all salinity concentrations compared with the control. The increase of band intensity and appearance or disappearance of new bands may be an indication of an increase in isozymes activities under salinity conditions.

\section{REFFERENCES}

Abdel-Tawab F. M., Fahmy Eman M., El Nahrawy M. A., Wafaa M. Sharawy and Sayed Mervat R. I. (2011). Detection of molecular markers associated with salt tolerance in alfalfa (Medicago sativa L.). Egypt. J. Genet. And Cytol., 40: 113-127.

Allen S. G., Dobrenz A. K. and Bartels P. G. (1986).Physiological response of salttolerant and nontolerant alfalfa to salinity during germination. Crop Sci., 26: 10041008.

Amal H., Arjun K., Madana M. R. A. and Andy P. (2010). Molecular and physiological analysis of drought stress in Arabidopsis reveals early responses leading to acclimation in plant growth. Plant Physiol., 154:1254-1271.
Ashraf M. (2004). Some important physiological selection criteria for salt tolerance in plants. Flora - Morphology, Distribution, Functional Ecology of Plants 199, 361376.

Azzam Clara R., Zeinab Abd-Elnaby and Azza Kh. Salem (2012). Influence of agroecological conditions on geneexpression, yield and yield components of the monocut (Fahl) type of berseem. Egypt. J. Plant Breed. 16(2): 135-159.

Bhardwaj S., Jain L. and Jain S. (2010). An Approach for Investigating Perspective of Cloud Software Service (SaaS). Int'1 J. Comput. Appl., 10(2): 40-43.

Carlson J. R. Jr., Ditterline R. L., Martin J. M., Sands D. C. and Lurid R. E. (1983).Alfalfa seed germination in antibiotic agarcontaining $\mathrm{NaCl}$. Crop Sci., 23: 882-885.

Deinlein U., Stephan A.B., Horie T., Luo W.,Xu G. and Schroeder J.I. (2014). Plant salttolerance mechanisms. Trends Plant Sci., 19 (6):371-9.

Dobrenz A. K., Robinson D. L., Smith S. E. and Poteet D. C. (1989).AZ-Germ Salt-II. Nondormant alfalfa germplasm. Crop Sci., 29: 493.

El-Sharkawy M. S., El-Beshsbeshy T. R., Mahmoud E. K., Abdelkader N. I., AlShal Rania M., and Missaoui A. M. (2017). Response of alfalfa under salt stress to the application of potassium sulfate nanoparticles. Amer. J. Plant Sci., 8: 1751-1773.

El-Sherif A.A.M. (2003). Breeding studies on drought and salinity tolerance in alfalfa. Ph.D. Thesis, Dept. of Agronomy, Fac. Agric. Suez Canal Univ., Ismailia, Egypt. 
Emam Y., Bijanzadeh E., Naderi R. and Edalat M. (2009). Effect of salt stress on vegetative growth and ion accumulation of two Alfalfa cultivars. Desert, 14: 163-169.

Gao W.R., Wang X.S., Liu Q.Y., Peng H., Chen C. , Li J.G., Zhang J.S., Hu S.N. and Ma H. (2008). Comparative analysis of ESTs in response to drought stress in chickpea (C. arietinum L). Biochem. Biophys. Res. Commun., 376: 578-583.

Golbashy M., Khavari K. S., Ebrahimi M. and Choukan R. (2010). Study of response of corn hybrids to limited irrigation. $11^{\text {th }}$ Iranian Crop Science Congress, Tehran, Iran, 24-26 July. University of Shahid Beheshti,Pp. 218.

Gomez K. A. and Gomez A. A. (1984). Statistical Procedures for Agricultural Research. John Wiley and Sons, Inc. New York, U.S.A.

Hamidi H. and Safarnejad A. (2010). Effect of drought stress on alfalfa cultivars (Medicago sativa L.) in germination stage. American-Eurasian J. Agric. \& Environ. Sci., 8 (6): 705-709.

Helmy Amal A., Abdel-Aziz T. K. and Sharawy Wafaa M. (2003). Effect of different concentrations of $\mathrm{NaCl}$ on growth, nodulation and chemical composition of alfalfa (Medicago sativa L.). The $10^{\text {th }}$ Conference of Agronomy. October 7-10, 2003, EL-Arish, Egypt.

ISTA (1985).International rules for seed testing.Proc. Int'1. Seed Test. Assoc.,:31:1-52.

Jonathan F.W. and Wendel N.F. (1990). Visualization and interpretation of plant isozymes. In: D.E. Solties and P.S. Solties, (eds) Isozymes in Plant Biology, London Chapman and Hall, pp: 5-45.

Katembe W.J., Ungar I.A. and MitchellJ.P. (1998). Effect of salinity on germination and seedling growth of two Atriplex species (Chenopodiaceae). Ann. Bot.82(2): 167-175.

Khan S.A., Mulvaney R.L. and Mulvaney C.S. (1997). Accelerated diffusion methods for inorganic-nitrogen analysis of soil extracts and water. Soil Sci. Am. J., 61: 936-942.

Mahgoub H. A. M., Sofy R. A., Abdel-Azeem E. A. and Abo-Zahra M.S.(2016). Molecular markers associated with salttolerance of different soybean (Glycine $\max$ L.) cultivars under salt stress. Int'1. J. Adv. Res. Biol. Sci.,3(8): 241-267.
Mass E.V. and Hoffman G.J. (1977).Crop salt tolerance: Current assessment. J. Irrig. Drainage Div., Am. Soc. Civ. Eng., 103:115-134.

Monirifar H. (2008). Determination of general combining ability with polycross test for Azerbaijan alfalfa ecotypes. Final report, project no: 101-12-81149. East Azarbayjan Agriculture and Natural Resources Research Center, Tabriz, Iran.

Monirifar H., Valizadeh M., Mohammadian R., Abedi M. S. and Milani A. O. (2004). Variation for tolerance in five alfalfa cultivars. International scientific symposium, Ganja. Azerbaijan,35 (4): 239-252.

Munns R., James A.J. and Lauchli A. (2006). Approaches to increasing the salt tolerance of wheat and other cereals. J. Experiment. Bot., 57, 1025-1043. https://doi.org/10.1093/jxb/erj100.

Noble C. L., Halloran G. M. and West D. W. (1984).Identification and selection for salt tolerance in Lucerne ( Medicago sativa L.). Aust. J. Agric. Res., 35: 239-252.

Rashed M.A., Eman M. Fahmy and M.A. Sallam (1994). Embryo culture, protein and isozyme electrophoresis as selectable markers to predict salt tolerance in wheat 5th conf. Agric Dev. Rs. Fac. Agric., Ain Shams Univ., Cairo, Egypt. 1:469-490.

Roy S.J., Negrao S.and Tester M. (2014).Salt resistant crop plants. Curr. Opin.Biotech.,26:115-24.

Saad-Allah K.M. (2015). Differential response to sea salt salinity by nitrate and antioxidant system in six soybean varieties. Cercetări Agronomiceîn Moldova, 4 (164):125- 137.

Soltani A., Khodarahmpour Z., Jafari A. A. and Nakhjavan Sh. (2012). Selection of alfalfa (Medicago sativa L.) cultivars for salt stress tolerance using germination indices. Afr.J. Biotech.,11(31):7899-7905.

Stegemann H., Burgermeister W., Franksen H. and Krogerrecklenfor E. (1985). Gel electrophoresis and isoelectric focusing: A laboratory manual, London Chapman and Hall, pp: 5-45. Braunschweig, WestGermany.

Torabi M., Halim R. A., Sinniah U. R. and Choukan R. (2011). Influence of salinity on the germination of Iranian alfalfa ecotypes. Afr. J. Agric. Res., 6: 46244630 . 
Turhan H. and Ayaz C. (2004). Effect of salinity on seedling emergence and growth of sunflower (Helianthus annuusL.) cultivars. Int'l. J.Agri. Biol., 6(1):149152.

Valizadeh M., Moharamnejad S., Ahmadi M. and Mohammadzadeh J. H. (2013). Changes in activity profile of some antioxidant enzymes in alfalfa half-sib families under salt stress. J. Agric. Sci. Tech., 15: 801-809.

Wang W.B., Kim Y.H., Lee H. S. Kim K.Y., Deng X.P. and Kwak S.S. (2009).
Analysis of antioxidant enzyme activity during germination of alfalfa under salt and drought stresses. Plant Physiol. Biochemistry, 47: 570-577.

Yarnia M. (2011). Crop yield physiology. Adv. Environ. Biol., 5(6):449- 457.

Yusefi M., Asl V. N. and Moharramnejad S. (2017). Responseofoxidative defense system to salt-treat in alfalfa (Medicago sativa L.). Fresenius Environ. Bul., 26(8): 5219-5224.

\section{تقييم سلالتين من البرسيم الحجازي لتحمل الملوحة من خلال بعض الصفات المورفولوجية والكيميائية الحيوية ناهد عبد العاطي علي - ميرفت رفاعي ابراهيم سيد* ـ فادية محمد سلطان*

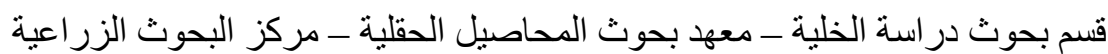

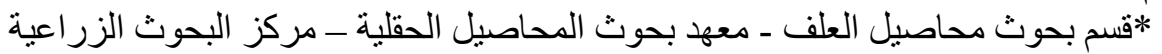

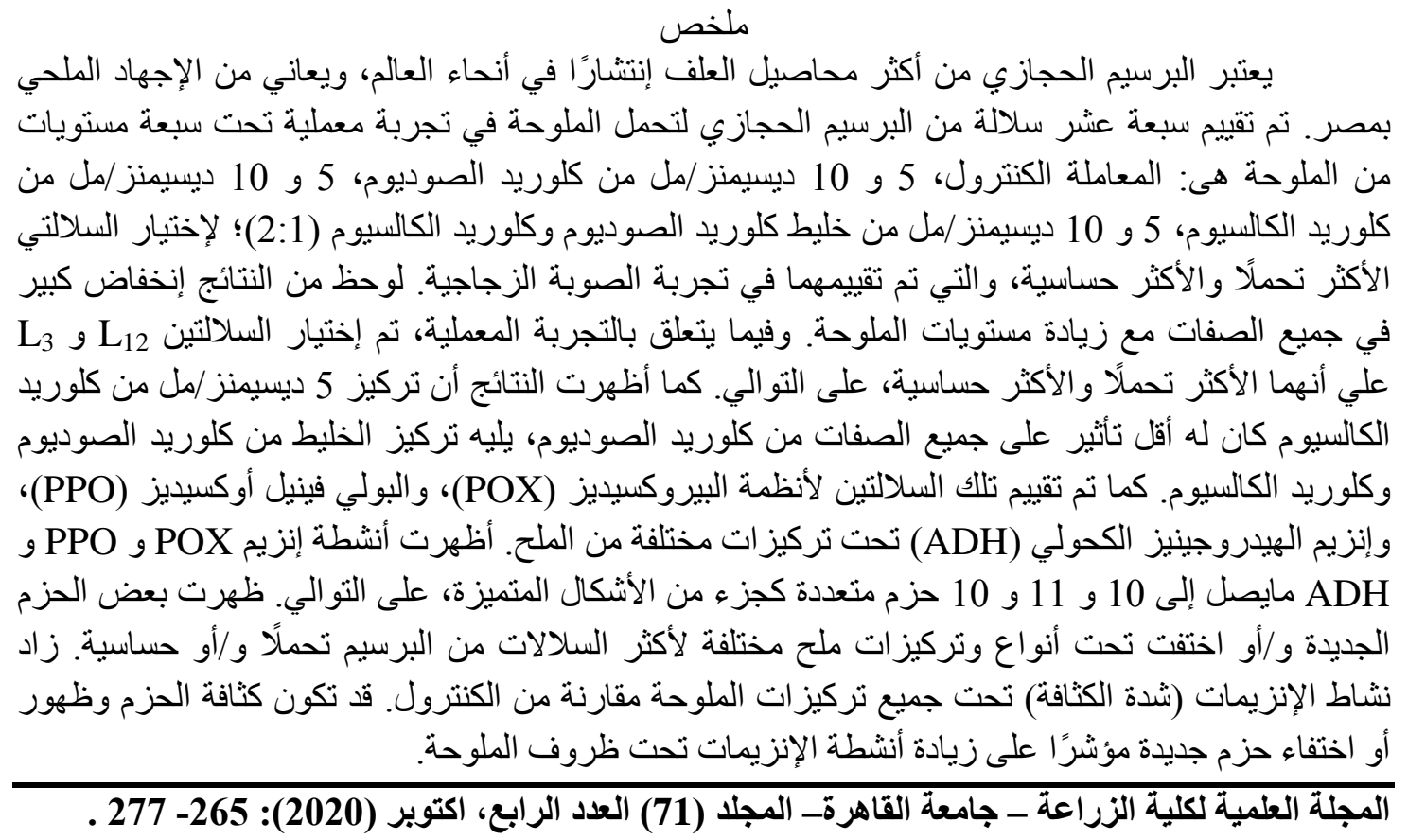

